\title{
Revisiting the antecedent of electronic word-of-mouth (eWOM) during COVID-19 Pandemic
}

\author{
Anshu Rani $(\mathbb{D} \cdot$ H. N. Shivaprasad
}

Accepted: 3 November 2021 / Published online: 30 November 2021

(C) Indian Institute of Management Calcutta 2021

\begin{abstract}
The main feature of the Internet and e-commerce is electronic word-of-mouth (eWOM) through online reviews. As Internet users and their consumption of eWOM for product information overgrow in India, it is vital to examine the elements that influence the effectiveness of eWOM communication during COVID-19 pandemics. A systematic literature review has been conducted to assess the factors influencing eWOM in the online retailing context. The literature has been segregated into WOM, eWOM, the eWOM source credibility, eWOM message characteristics, eWOM platform, and outcome of eWOM adoption. The organised review provided a eWOM communication model and proposed an appropriate hypothesis to be tested. The finding concludes the significant relationship of eWOM determinants in building purchase intention, brand image, and attitude during COVID-19 pandemics. Previously conducted research examined the effect of source and message credibility; however, source homophily and website credibility in eWOM communication are rarely taken
\end{abstract}

A. Rani $(\bowtie)$

REVA Business School, REVA University, Bangalore, India

e-mail: meetanshu2504@gmail.com

H. N. Shivaprasad

Dr. D Veerendra Heggade Institute of Management Studies \& Research, JSS Campus, Vidyagiri, Dharwad, India

e-mail: sprasad_hn@ rediffmail.com into account along with these constructs. This study will address more vigorous eWOM phenomena and empirical findings in the COVID-19 period. The study's findings will help practitioners manage the power of eWOM communication for all stakeholders.

Keywords Electronic word-of-mouth; consumer behaviour - Online review - COVID-19 - Online retailers - Source credibility; Source homophily; Message credibility; Website credibility

\section{Introduction}

Researchers have shown the importance of word-ofmouth (WOM) impact on the behaviour of consumers (Katz \& Lazarsfeld 1955; Arndt 1967). New media expansion has increased its relevance in the market. New technologies facilitate sharing of product and brand information amongst customers (Ardyan et al. 2021). This new technique of exchanging product information is regarded as electronic word-of-mouth (eWOM) and have been defined as "any positive or negative announcement made by potential, current or former customers concerning a product or company made available through the Internet to many persons and institutions" (Hennig-Thurau et al. 2004, p. 39). In recent researches, it has been highlighted that eWOM has been influencing consumer behaviour, like 
traditional WOM (Park and Kim 2008; Rani \& Shivaparsad 2019), and has a direct relation to sales (Verma and Yadav 2021; Wang 2011).

The emergence of the Internet plays a critical role in today's economy and social life, which has become almost essential for daily communication (Shivaprasad \& Rani 2020). Although eWOM marketing has always existed, it is now more relevant than ever. This relevance is primarily due to people spending more time at home and on computers than they would otherwise do due to COVID-19 (Ardyan et al. 2021). As a result, the story of a customer's positive or negative experience will most likely be shared online in a matter of sometime (Jake 2020). According to Kotler (2020), it is predicted that the power of eWOM will grow during COVID-19 and will increase its influence in shaping consumer behaviour (Kotler 2020). In this condition, it is essential to know the key factors that differentiate a high-impact eWOM from sheer volume.

The number of articles published on eWOM communication has recently increased due to its growing significance (Baur and Nystrom 2017; O'Reilly et al. 2016; Kim et al. 2018; Wern et al. 2016; Wu 2013; Zarrad \& Debabi 2015; Rani \& Shivaprasad 2018); however, the reach of published literature is vast and fragmented. Cheung and Thadani (2012) examined 83 papers published between 2001 and 2010, looking for methodological and theoretical underpinnings of eWOM. Mishra and Satish (2016) used theoretical foundations to summarise the current literature in the eWOM domain and identify a few research areas. Previous research in the area has taken source-related factors to establish credibility in eWOM communication (Chau et al. 2009; Wang 2011; O'Reilly et al. 2016; Rani \& Shivaprasad 2019). Researchers have also established the role of message content in perceived eWOM effectiveness (Lee \& Lee 2009; Wang 2011; Yayli et al. 2012; Cheung \& Thadani 2012; Ismagilova et al. 2020). There are limited empirical studies examining these source and message characteristics together. Most of these studies have examined eWOM on social media context and there are only limited studies available on investigating online reviewers on e-tailing websites (O'Reilly et al. 2016).
On the other hand, there is a considerable increase in online platforms (e.g. Social media, blogs, virtual communities, e-commerce site, review sites, etc.) to share the opinion \& experiences about product and service consumer makes use of (Gupta \& Harris 2010; Lee et al. 2012; Rani \& Shivaprasad 2018) and to research the companies that sell them. However, eWOM process is a comprehensive communication model, wherein, source credibility, message credibility, and medium/platform credibility influence its effectiveness but have rarely been examined together. So far, very few studies have attempted to take such large pool of determinants in empirically predicting eWOM effectiveness (Wang 2011; Mishra 2016). A comprehensive model of eWOM communication is vital particularly in Indian context due to unavailability of such investigation.

During COVID-19, the growth of eWOM was more than double which rapidly increase the volume of eWOM worldwide (Luo \& Xu 2021). These eWOM during pandemic are recent and would act as a predictor of new normal. It would be interesting to see the role of existing antecedent's consequence on the effectiveness of eWOM. Hence, it is essential to measure the actual worth and performance of eWOM communication as a whole rather volume or one part of it. The main objective of this paper is to identify the factors influencing the effectiveness of eWOM communication in the form of online reviews written at online retailer's websites in India. The present research will attempt to comprehend eWOM communication as a whole and present a broader perspective of the eWOM communication process during COVID19 pandemics. The factors addressed in determining eWOM effectiveness of online reviews are likely to help marketers understand the main determinants of high impact eWOM during the COVID-19 pandemic and enhance company's products, websites, and branding strategies in coming times. The proposed antecedent will contribute in the prediction of high impact eWOM, which has the potential to influence purchase intention, attitude, and brand image of firm in new normal. Marketers and customers will make more informed decisions, increasing the utility of online reviews on online retailing platforms which will also 
contribute to enhancing academic knowledge in area of e-commerce.

\section{Literature Review and hypothesis development}

The eWOM communication in the form of online product reviews, ratings, and other online content is present in all shots of online platforms like online websites, online communities, and social media (Chevalier et al. 2006). eWOM is an extension of WOM communication in many ways. Ismagilova et al. (2017) has shown a positive association between eWOM and consumer behaviour towards business. Godes and Mazylin (2004) have stated that eWOM is an outcome of a firm's past performance and drives a firm's future performance. eWOM is one of the essential sources of customer acquisition through different channels. eWOM has a long-term impact on consumer acquisition, consumer retention, and consumer post-purchase evaluation (Rani \& Shivaprasad 2019). Many research scholars who have contributed to the field of literature, such as Cheng and Zhou (2010), Litvin et al. (2008), Wu et al. (2013), have adopted this interpretation of eWOM. EWOM communication is distributed through a network, primarily the Internet, and is directed to a large number of people for future access (Breazeale 2009; Subramani and Rajagopalan 2003). Product satisfaction, loyalty, commitment, trust, involvement, and benefits are the qualifications for giving WOM and eWOM (Neumann 2015).

\section{Theoretical foundation of study}

Elaboration likelihood model (ELM) is a theory proposed around 1980s to explain the persuasion process (Petty \& Cacioppo 1986). ELM is a popular theory in the eWOM literature and often explains the change in attitude, belief, and behaviour based on two parallel routes of cognition. Based on high and low elaboration of information, receiver determines the central or peripheral route of processing. Consumer who gets involved with eWOM communication can choose any route based upon their motivation and ability to change behaviour. Further, the antecedents of eWOM effectiveness will be discussed in line with communication model and ELM.
eWOM antecedents

The antecedent for eWOM effectiveness has been meticulously analysed from available literature to understand the complete mechanism of eWOM communication systematically (Cheung and Thadani 2012; Rani \& Shivaprasad 2019). The antecedents are further divided into elements of the communication process that is source, message, and medium which are discussed below. To align this with ELM, message-related factors are central route of persuasion, and source-related as well as website-related factors are the peripheral route of persuasion.

Factors related to source of eWOM communication

The perceived usefulness of eWOM communication is determined by source credibility. The degree to which a communicator is regarded as a reliable source of information is known as source credibility (Rani \& Shivaprasad 2018; Shivaprasad \& Rani 2020). The basis of source credibility is built on the assumption that the communicator is unbiased, independent of marketer influence, and provides accurate information. A credible source of eWOM communication is determined by how believable, knowledgeable, and trustworthy a communicator is viewed (Petty and Cacioppo 1986). As a result, source credibility indicates that the message will be perceived as believable, knowledgeable, and trustworthy by the receiver (AlHaidari 2014; Shivaprasad \& Rani 2020). Source credibility is more significant in eWOM communication than conventional WOM communication since the personal tie is often not present in virtual relationships.

\section{Source credibility}

To better understand eWOM communication, this study will look at source credibility as a significant independent variable. One of the factors that contribute to source credibility is source trustworthiness (Saremi 2014). The aspect of trust is based on source identity cues. As a result, source trustability regulates source credibility and indirectly impacts the overall effectiveness of eWOM (Daowd et al. 2021; Ngarmwongnoi et al. 2020; O'Reilly et al. 2016; Kim et al. 2018; Wern et al. 2016; Wu 2013). In addition, the 
source ability to demonstrate relevant information about actual product usages significantly impacts the source (Cheung et al. 2012; Senecal et al. 2004; O'Reilly et al. 2016; Wu 2013). When a source is considered to have a high level of expertise, eWOM communication is more efficient.

\section{Source-receiver homophily}

Source homophily has been confirmed as a noteworthy variable in the effectiveness of WOM and eWOM. Prior studies like Brown and Reingen (1987), Bruyn and Lilien (2004), Hawkins (2008), Steffes and Burgee (2009), Saleem \& Ellahi (2017), etc. have included source homophily as a significant element in their study of WOM and eWOM studies. 'Homophily' has been regarded as a persuasive element in social structure formation. ELM and previous studies suggest that people often prefer those individuals who are similar to them. This similarity increases their interpersonal attractiveness and persuasion abilities through peripheral route of information persuasion (Beyers \& Braun 2014). Source homophily can be defined as the degree to which individuals are similar in age, gender, education, and social status (Chaung and Thadani 2012; Rani \& Shivapasad 2018).

\section{eWOM message characteristics to determine credibility}

The evaluation of the eWOM message concerns the credibility of the message. Many previous studies have tested the features using text analysis to understand the effect of the message on eWOM adoption (Davis and Khazanchi 2008; Yayli and Bayram 2012; Rani et al. 2021). The content of the eWOM message and its presentation indicates that it can be believed or not. Message valence, message volume, message presence, message consistency, message quality, message emotion, and message ratings are characteristic of the eWOM messages that affect its effectiveness (Chaung and Thadani 2012; Yayli and Bayram 2012; Rani \& Shivaprasad 2018). The message's argument power determines the content quality of a eWOM message, and it plays a vital role in knowledge influence to receivers (Wu et al. 2011; Ismagilova et al. 2017; Wern et al. 2016). The evaluation of the components mentioned above, presentation, and substances in the eWOM message supports the credibility and encourages eWOM adoption. ELM also argues that messages-related factors \& its content is the central route of attitude formation and behaviour.

However, there is sufficient evidence in the current literature to demonstrate the importance of message valence (positive, negative, or neutral) and message volume in designing message credibility for eWOM messages. On the other hand, other defining variables are understudied (Cheung \& Thadani 2012; Rani \& Shivaprasad 2018). But assessing the overall message characteristics and the overall effect of eWOM will be important during COVID19.

\section{Method/Platform for obtaining eWOM}

Although various platforms provide eWOM, they can be divided into two groups. The first is 'Providergenerated,' and the second is 'Third-party' (Saremi 2014). However, the majority of eWOM messages are found on third-party websites like online retailers. Table 1 lists the overall variables that influence eWOM effectiveness:

\section{Outcome response of eWOM adoption}

The eWOM is a highly effective mechanism for generating a response to a product. In recent years, researchers have begun to examine the impact of eWOM on customer response and business outcomes (Godes and Mayzlin 2004). If the eWOM communication generates valuable information, it activates a response in consumer behaviour (Cheung and Thadani 2012). The most widely recognised response/outcome of eWOM communications impacts attitude formation (whether positive or negative), purchase intention, and purchase (Rani \& Shivaprasad 2018). Cheung (2005) attempted to create and validate a connection between attitude, purchase intentions, and actual purchase. Their results indicate that attitude has a significant effect on purchase intention, while online purchase intention has a beneficial impact on purchases. Additionally, the principle of reasoned action supports these relationships (Fishbein and Ajzen 1977). The primary goal of eWOM communication is to elicit a response from consumers. Numerous studies of WOM and eWOM are devoted to exploring the influences of consumer behaviour. Numerous studies have discovered that word-of-mouth has a significant impact on 
Table 1 Factors related to eWOM Variables

\begin{tabular}{|c|c|c|}
\hline Variables & Definition with Author & $\begin{array}{l}\text { The author who associated variable with eWOM } \\
\text { effectiveness }\end{array}$ \\
\hline \multicolumn{3}{|c|}{ Source-related variables } \\
\hline $\begin{array}{l}\text { Source } \\
\text { credibility }\end{array}$ & $\begin{array}{l}\text { Consumers' perceptions of the sources of eWOM } \\
\text { recommendation (Cheung et al., 2008; Senecal \& } \\
\text { Nantel, 2004) }\end{array}$ & $\begin{array}{l}\text { Chau et al. (2009); Wang (2011); Lerrthaitrakul and } \\
\text { Panjakajornsak (2014); O'Reilly et al. (2016); Rani \& } \\
\text { Shivaprasad (2019) }\end{array}$ \\
\hline $\begin{array}{l}\text { Source } \\
\text { trustability }\end{array}$ & $\begin{array}{l}\text { Consumer Perception about the authenticity of source or } \\
\text { being accurate (Kelley et al. (2016) }\end{array}$ & $\begin{array}{l}\text { Wang (2011); O’Reilly et al. (2016); Kim et al. (2018); } \\
\text { Rani \& Shivaprasad (2019) }\end{array}$ \\
\hline $\begin{array}{l}\text { Source } \\
\text { knowledge }\end{array}$ & $\begin{array}{l}\text { Source's expertise in processing information and } \\
\text { relevant experience about the eWOM recommendation } \\
\text { (Cheung et al. 2009; Senecal \& Nantel 2004) }\end{array}$ & $\begin{array}{l}\text { O’Reilly et al. (2016); Kim et al. (2018); Warn (2018); } \\
\text { Rani \& Shivaprasad (2019) }\end{array}$ \\
\hline Tie strength & $\begin{array}{l}\text { The level of intensity of a social relationship between } \\
\text { the source of eWOM recommendation and the } \\
\text { consumer (Cheung \& Thadani 2012) }\end{array}$ & $\begin{array}{l}\text { Saleem \& Ellahi (2017); Rani \& Shivaprasad } \\
\quad(2018,2019)\end{array}$ \\
\hline \multicolumn{3}{|c|}{ Source similarity-related factor } \\
\hline $\begin{array}{l}\text { Source } \\
\text { homophily }\end{array}$ & $\begin{array}{l}\text { The degree to which the source of the eWOM } \\
\text { recommendation and the recipient are similar (Cheung } \\
\& \text { Thadani 2012) }\end{array}$ & Wang (2011); Neumann (2015); Rani et al. (2021) \\
\hline \multicolumn{3}{|c|}{ eWOM message-related factors } \\
\hline eWOM valence & $\begin{array}{l}\text { The valence of an eWOM recommendation shows } \\
\text { whether the message is positive or negative (Cheung \& } \\
\text { Thadani 2012) }\end{array}$ & $\begin{array}{l}\text { Park \& Lee (2009); Wang (2011); BI Jidong (2012); } \\
\text { Rani \& Shivaprasad, (2018) }\end{array}$ \\
\hline eWOM volume & The number of eWOM recommendations & $\begin{array}{l}\text { Davis \& Khazanchi (2008); Lerrthaitrakul and } \\
\text { Panjakajornsak (2014) }\end{array}$ \\
\hline $\begin{array}{l}\text { eWOM } \\
\text { presence }\end{array}$ & $\begin{array}{l}\text { eWOM communication availability about product } \\
\text { (Gupta \& Harris 2010) }\end{array}$ & Cheung \&Thadani (2012); Yayli et al. (2012) \\
\hline $\begin{array}{l}\text { eWOM } \\
\text { consistency }\end{array}$ & $\begin{array}{l}\text { Congruence with other's opinions (Cheung \& Thadani } \\
\text { 2012; Cheung et al. 2009) }\end{array}$ & Wang (2011); Cheung \&Thadani (2012) \\
\hline $\begin{array}{l}\text { eWOM } \\
\text { emotions }\end{array}$ & $\begin{array}{l}\text { Extent and type of emotional expressions used in the } \\
\text { eWOM recommendation (Yin et al. 2014) }\end{array}$ & Ismagilova et al. (2020) \\
\hline $\begin{array}{l}\text { eWOM } \\
\text { argument } \\
\text { quality }\end{array}$ & $\begin{array}{l}\text { The quality and strength of argument in eWOM message } \\
\text { (Yayli et al. 2012) }\end{array}$ & $\begin{array}{l}\text { Lee \& Lee (2009); Cheung \&Thadani (2012); Yayli } \\
\text { et al. (2012); Rani \& Shivaprasad (2018) }\end{array}$ \\
\hline eWOM ratings & $\begin{array}{l}\text { Consumers give the overall ratings for an eWOM } \\
\text { recommendation (Lee \& Lee 2009) }\end{array}$ & Lee \& Lee (2009); Rani et al. (2021) \\
\hline \multicolumn{3}{|c|}{ Platform-related factor } \\
\hline $\begin{array}{l}\text { Website } \\
\text { characteristics }\end{array}$ & $\begin{array}{l}\text { Website or website-related characteristics which help } \\
\text { eWOM message availability (Alexander Benlian et al. } \\
\text { (2010) }\end{array}$ & Cheng \& Zhou, (2010); Ali (2018); Rani et al. (2021) \\
\hline $\begin{array}{l}\text { Third-party } \\
\text { website }\end{array}$ & $\begin{array}{l}\text { Other websites which are not sponsored by products/ } \\
\text { brands like SNS, Blogs, e-tailers etc. (Mudambi \& } \\
\text { Schuff 2010) }\end{array}$ & $\begin{array}{l}\text { Lerrthaitrakul and Panjakajornsak (2014), Cheng \& } \\
\text { Zhou (2010); Ali (2018) }\end{array}$ \\
\hline
\end{tabular}

customer choice, understanding, tastes, mood, purchasing intention, purchase, and post-purchase behaviour (e.g. Katz and Lazarfeld 1955; Arndt 1967; Brown and Reingen 1987; Zhang et al. 2010). Since the answer to eWOM communication is oriented around product purchasing, this research is crucial for further investigation. The table below 2 illustrates the effect of eWOM on consumer behaviour. 
Table 2 Impact of eWOM on consumer behaviour

\begin{tabular}{lll}
\hline Parameter & Particulars & Publication \\
\hline $\begin{array}{l}\text { Impact of eWOM on } \\
\text { consumer behaviour }\end{array}$ & $\begin{array}{c}\text { Purchase } \\
\text { Intention } \\
\text { Product Choice } \\
\text { and Attitude } \\
\text { Branding }\end{array}$ & $\begin{array}{c}\text { Zhang et al. (2010); Amblee \& Bui (2011); Jalivand et al. (2012); Seeto \& Ho } \\
\text { (2014); Torlak et al. (2014) and Kala \& Chaubey (2018) }\end{array}$ \\
& Kupta and Harris (2010); Zhang et al. (2010); Amblee \& Bui (2011) \\
& & Kim and Gupta (2012); Rani et al. (2021) \\
\hline
\end{tabular}

Table 3 Demographic Profile of Respondents

\begin{tabular}{|c|c|c|c|}
\hline Characteristics & Category & Frequency & Percentage \\
\hline \multirow[t]{2}{*}{ Gender } & Male & 295 & 58.65 \\
\hline & Female & 208 & 41.35 \\
\hline \multirow[t]{5}{*}{ Age (in Years) } & $16-25$ & 214 & 42.54 \\
\hline & $26-35$ & 181 & 35.98 \\
\hline & $36-45$ & 85 & 16.90 \\
\hline & $45-55$ & 19 & 3.78 \\
\hline & $55+$ & 4 & 0.80 \\
\hline \multirow[t]{3}{*}{ Marital status } & Married & 232 & 46.12 \\
\hline & Unmarried & 266 & 52.88 \\
\hline & Widow/ Divorcee & 5 & 0.99 \\
\hline \multirow[t]{4}{*}{ Monthly income (Rs) } & Less than 40,000 & 251 & 49.90 \\
\hline & $40,000-80,000$ & 123 & 24.45 \\
\hline & $80,000-1,20,000$ & 68 & 13.52 \\
\hline & More than $1,20,000$ & 61 & 12.13 \\
\hline \multirow[t]{6}{*}{ Occupation } & Self- employed & 60 & 11.93 \\
\hline & Public sector employee & 30 & 5.96 \\
\hline & Private sector employee & 194 & 38.57 \\
\hline & Housewife & 100 & 19.88 \\
\hline & Students & 117 & 23.26 \\
\hline & Pensioner & 2 & 0.40 \\
\hline
\end{tabular}

Theoretical framework and hypothesis

The research studies in eWOM have confirmed that consumers are influenced by eWOM communication in their decision-making process. The adoption of eWOM specifically influences purchase intention and purchase for both online and offline sales categories. The conceptual model examined in the study is presented as followed: 


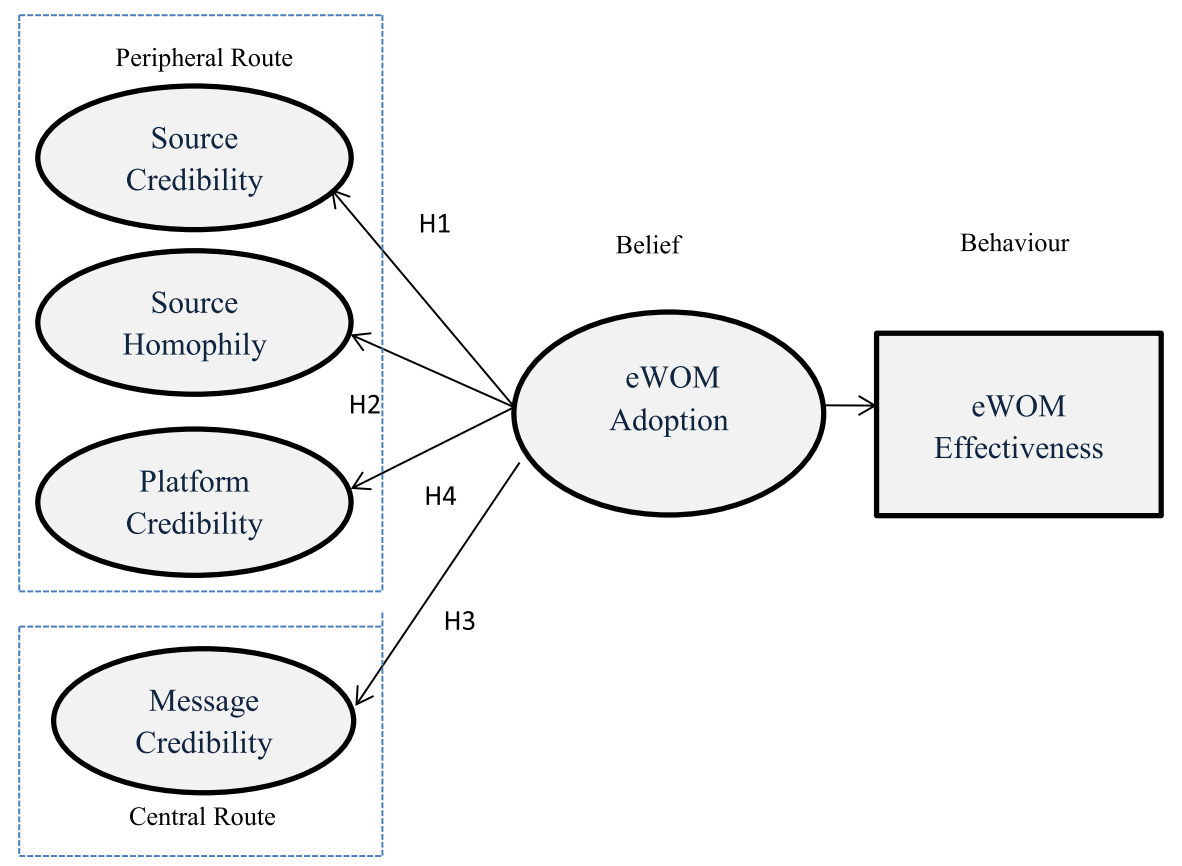

The content of eWOM helps the consumer in making choices and forming an attitude towards the desired product. Moreover, it fulfils the need for information to compare the products conveniently. From a firm's perspective, eWOM improves the reputation of the product, brand, and firm. eWOM is an important element in branding activities that helps in developing trust for the brand. Therefore, it will be interesting to examine the variable mentioned above in the COVID-19 context.

\section{Research design and sampling}

Academic research is guided by the set of practices, beliefs, and assumptions that frame how the researcher approaches the investigation. The current study adopts a quantitative method of research design to approach the research questions. In order to understand the respondent's opinion about the key drivers of the construct and establish relationships among them, a quantitative approach is appropriate (Creswell 2013; Vogt 2006). This study examines the inter-relationships among the construct variables. During the questionnaire design, the study has chosen a mixed method of explanatory and descriptive methods. Instead, this study seeks to fill the gap in the existing literature by clarifying the phenomenon which is not fully captured by existing literature.

\section{Sampling and procedure}

The sampling design of a quantitative research study plays a major role in generalising research findings. The target population of this study is those consumers who give or/and seek eWOM over the online retailing site in the form of online reviews. The study considers the consumers of top online retailers in India who purchase consumer electronic products between April 2020 and January 2021. The sample size for the study should be estimated with a standardised effect size rather than 30,50 , or 100 . However, a ratio of the item to the respondent of 1:10 can be considered acceptable. The scale of measurement used for this study has 26 items in all, and therefore 260 respondents can be regarded as standard to conclude the findings of the study. However, the sample size is deliberately kept above 500 to obtain better SEM results. The total sample considers for the study is 503 responses. The online method is used to collect data from the respondent by considering the COVID-19 pandemic situation in India.

Factor analysis is a systematic procedure to find out latent factors that create commonality; this study has 
Table 4 Model fit indices for CFA model

\begin{tabular}{|c|c|c|c|c|}
\hline Goodness-of-fit Statistics & & Values & Desired range of values for good fit & Interpretation \\
\hline \multicolumn{5}{|l|}{ Absolute Fit Measures } \\
\hline Chi-square & $\chi^{2}$ & 452.19 & $p>.05$ & \\
\hline Degree of Freedom & df & 137 & 0 & \\
\hline Chi-square /Degree of Freedom ratio & $\chi 2 /$ d.f & 3.301 & $<5.0$ & Acceptable \\
\hline Goodness-of-fit Index & GFI & 0.915 & $>0.90$ & Acceptable \\
\hline Root mean square error of apprx & RMSEA & 0.068 & $\leq 0.06$ & Acceptable \\
\hline \multicolumn{5}{|l|}{ Incremental Fit Measures } \\
\hline Adjusted good-of-fit Index & AGFI & 0.892 & $>0.90$ & Threshold value \\
\hline Tucher-Lewis Index & TLI & 0.937 & $>0.90$ & Acceptable \\
\hline Normal fit Index & NFI & 0.929 & $>0.90$ & Acceptable \\
\hline Comparative fit Index & CFI & 0.949 & $>0.90$ & Acceptable \\
\hline \multicolumn{5}{|l|}{ Parsimonious fit Measures } \\
\hline Parsimonious normal fit Index & PNFI & 0.745 & $>0.50$ & Acceptable \\
\hline Parsimonious goodness-of-fit Index & PGFI & 0.66 & $>0.50$ & Acceptable \\
\hline
\end{tabular}

used this statistical analysis (Bartholomew, Steele, Galbraith, \& Moustaki, 2008). Confirmatory factor analysis (CFA) has also been used in the current study to examine the relationships of the reflective construct. Finally, structure equation modelling (SEM) has been used for regression analysis of the model where independent variables loading on dependent variables will be evaluated.

\section{Results}

The study considered different parametric tests to check the relationships drawn from the theory. To justify the test results of the study, the sample must satisfy some thumb rules such as normality of data, the interval of data, and independence of parameters (Field 2009, p.133). The Interval and independence of data were taken into consideration at the time of measurement. In contrast, the normality of the sample has been tested before applying any relevant statistical technique of analysis. To perform SEM analysis, it has been observed to assess common method variance (CMV). The application of factor analysis has revealed that the 1st-factor loading is extracted as $41.78 \%$, which is less than the threshold level of 50\% (Podsakoff et al. 2003). Indicative demographic information of targeted respondents is discussed in Table 3.

The measure of model fit for all independent variable

The association between the latent variable and their indicative items has been assessed by establishing the structural relationship and the model fit. For the study, five latent variables, that is, source credibility (SC), source homophily ( $\mathrm{SH})$, message credibility (MC), and website/platform credibility (WC) on eWOM (EW) are considered, and the model fit indicators are presented ahead. Before examining the structural model of the measurement model needs to be assessed through confirmatory factor analysis (CFA).

The CFA analysis logically and systematically indicates the construct of EW. After primary CFA, SC is denoted by 7 items, $\mathrm{SH}$ is represented by 3 items, MC is denoted by 7 items, and WC by 2 items. First, a first-order analysis is carried out with the help of SPSS AMOS and then the second-order analysis has been done. In both the models, the loading of all items is above 0.5 and signifying the goodness-of-fit of the model. The summary of model fit is presented below in Table 4, with the regression weightage of each item is represented in Table 5. The table below shows that 
all the items which have been taken into consideration are significant.

The model fit parameters have been achieved for this model. The Chi-square divided by degrees of freedom values is expected to be in the range of 2- 5 for a good model fit, which is achieved in the results of the considered model. However, the other values like root mean square error of approximation (RMSEA), normed fit i (NFI), Tucker-Lewis coefficient index (TLI), comparative fit index (CFI), goodness-of-fit index (GFI), and adjusted goodness-of-fit index (AGFI) are at acceptable parameter (Hair et al. 2009). The CFA results meet the requirements of model fit; however, certain values are at the boundary level.

All the items with a greater loading than the value of 0.5 , have been retained in the model. The SEM Model is tested, and the result is presented to signify the relationship among all the considered sub-construct. SC, SH, MC, and WC are established significant to predict outcome variable of 'EW'. The result of second-order CFA analysis shows that there is a meaningful relationship that exists between $\mathrm{SC}$ and EW, between MC and EW as well as between WC and EW.

Further, the SEM model is tested to check and establish a relationship between independent variables and dependent variables. The SEM Model is tested, and the result is presented to signify the relationship among all the considered sub-construct. SC, SH, MC, and $\mathrm{WC}$ are established significant to predict outcome variable of 'EW'. The result of second-order CFA analysis shows that there is a meaningful relationship that exists between SC and EW, between MC and EW as well as between WC and EW. The model represents the multidimensional construct and is presented in SEM Figure as well as in model fit indices. All the measured values are above-accepted level (hair et. el. 2009), so the construct is found significant in the study. Table 6 illustrates the different measures of model fit. From Table 6, not only the model fit index values are represented, but also the comparison of CFA to SEM model fit is shown. The results give a better fit when path analysis is done. Therefore, the independent variables, i.e. SC, $\mathrm{SH}, \mathrm{MC}$, and $\mathrm{WC}$, significantly affect the dependent variable, i.e. EW.

The regression values are the significant evidence to examine the proposed hypothetical relationship. Table 7 presents the results of the structural model by displaying the regression values. The relationship between SC, SH, WC and MC and its predicting variable EW is supported statistically and therefore, the Hypothesis proposed in the conceptual model stands significant.

The items of the scale are correlated with the latent factors so after a path analysis of all independent variables (SC, SH, MC, and $\mathrm{WC}$ ) and dependent variable $(\mathrm{EW})$, it is the indication of nomological validity. For establishing the discriminant validity, the observed average variance extracted (AVE) value is also often considered. Further, the values of composite reliability (CR) are calculated for each sub-construct of study. The construct reliability is shown with a value greater than 0.6 , which is considered good. The values of AVE and CR are presented in Table 8.

The testing of direct relationships between $\mathrm{SC}, \mathrm{SH}$, WC, and MC found that they directly affect EW at 95\% significance level. In addition, the various indicator and fit indices prove that the paths in the structural model are significant.

\section{Discussion and implication}

This study investigated the empirical relationship between four antecedents: Source credibility, source homophily, message characteristics, and website credibility on eWOM effectiveness during COVID19 pandemics in India. The eWOM effectiveness construct has three indicators that reflect the concept. The empirical finding indicated that eWOM is perceived by purchase intention, attitude, and brand image. Therefore, the measure of eWOM is significant and determines that eWOM effectiveness is regulated by purchase intention, attitude, and brand image. Various studies have proved the relationship, like Torlak et al. (2014) and Kala \& Chaubey (2018) in context of social media.

First, the source of eWOM communication has been discussed in this section. The source component of the measurement model had two sub-constructs that are source credibility and source homophily. Source credibility has been measured by-"Trust on Source", "Knowledge of Source" and "Similarity of Personal Attribute with receiver". So, it is proved from results that "Source credibility" positively contributes to establishing "eWOM effectiveness". Evaluation results reveal that credibility depends on having 
Table 5 Regression Analysis weightage for CFA Model

\begin{tabular}{|c|c|c|c|c|}
\hline \multicolumn{5}{|c|}{ Regression Weights: 1st order model } \\
\hline Items & Estimate & S.E & $P$ & Std. Estimate \\
\hline $\mathrm{SC} 1$ & 1 & & & 0.803 \\
\hline $\mathrm{SC} 2$ & 1.044 & 0.047 & $* * *$ & 0.758 \\
\hline $\mathrm{SC} 3$ & 1.015 & 0.057 & $* * *$ & 0.765 \\
\hline $\mathrm{SC} 4$ & 1.046 & 0.053 & $* * *$ & 0.809 \\
\hline SC5 & 1.167 & 0.06 & $* * *$ & 0.79 \\
\hline SC6 & 1.089 & 0.059 & $* * *$ & 0.821 \\
\hline SC7 & 1.101 & 0.058 & $* * *$ & 0.78 \\
\hline SH1 & 1 & & & 0.868 \\
\hline $\mathrm{SH} 2$ & 1.122 & 0.058 & $* * *$ & 0.919 \\
\hline SH3 & 0.559 & 0.051 & $* * *$ & 0.505 \\
\hline WC1 & 1 & & & 0.786 \\
\hline WC2 & 0.881 & 0.146 & $* * *$ & 0.755 \\
\hline MC1 & 1 & & & 0.704 \\
\hline MC2 & 1.08 & 0.055 & $* * *$ & 0.777 \\
\hline MC3 & 1.194 & 0.071 & $* * *$ & 0.806 \\
\hline MC4 & 1.191 & 0.066 & $* * *$ & 0.861 \\
\hline MC5 & 1.181 & 0.071 & $* * *$ & 0.79 \\
\hline MC7 & 1.171 & 0.07 & $* * *$ & 0.796 \\
\hline MC9 & 0.968 & 0.085 & $* * *$ & 0.608 \\
\hline
\end{tabular}

Note: Estimates are the Unstandardized Estimate, S.E is Standard Error, $P$ is significance and Std. Estimate is a standardised estimate of regression

sufficient experience and trust. In other words, a higher credible source of eWOM will significantly influence the purchase intention, consumer attitude, and brand image, which were the indicators of eWOM effectiveness construct. In other words, there is a direct positive association between Source credibility and eWOM influence. These results are in line with many priories studies like Daowd et al. 2021; Ngarmwongnoi et al. 2020; O'Reilly et al. 2016; Kim et al. 2018; Wern et al. 2016; Wu 2013; Rani et al. 2021, has confirmed the findings even during COVID-19 times.
Table 7 Regression Weights: SC, SH, MC and WC on EW model

\begin{tabular}{llll}
\hline Items & Std. Estimate & S.E & $P$ \\
\hline SC <-- EW & .66 & 0.047 & $* * *$ \\
SH $<--$ EW & .34 & 0.057 & $* * *$ \\
MC $<--$ EW & .65 & 0.053 & $* * *$ \\
WC $<--$ EW & .72 & 0.06 & $* * *$ \\
\hline
\end{tabular}

Source homophily is also found to be a significant antecedent of the eWOM construct and resembles the studies from literature (Saleem \& Ellahi 2017).

The next dimension of our construct is message characteristics and their impact on eWOM communication. Characteristics like message valence have indicated the dimension of message characteristics, message volume, message rating, and consistency in the message, message argument quality and emotions expressed in the message. The study confirms that both-sided messages, including positive and negative information, are more credible (Wang 2015). Neutral reviews or both-sided messages affect the purchase intention, attitudes, and buying behaviour of customers more than negative reviews, which contradicts studies claiming that a negative WOM message has a greater influence on the brand assessment. Additionally, the message credibility is also ensured by message volume, rating, and argument quality, which in return influence eWOM effectiveness during this COVID-19 pandemic. Overall, the study provided enough evidence to conclude the characterises of the message in predicting a high degree of influence on readers. Many previous studies also supported the finding of this research (Wu et al. 2011; Ismagilova et al. 2017; Wern et al. 2016).

Beyond the dimensions of source and message, this study also considers website credibility as an indicator of eWOM effectiveness, and this is the uniqueness of the current research. The dimension of website

Table 6 Comparative fit indices of CFA and SEM Models of EW

\begin{tabular}{|c|c|c|c|c|c|c|c|c|c|}
\hline EW Model & $\chi^{2 / \text { d.f }}$ & GFI & RMSEA & AGFI & TLI & NFI & CFI & PNFI & PGFI \\
\hline CFA & 3.301 & 0.915 & 0.068 & 0.882 & 0.937 & 0.929 & 0.949 & 0.745 & 0.66 \\
\hline SEM & 3.163 & 0.903 & 0.066 & 0.87 & 0.933 & 0.922 & 0.945 & 0.758 & 0.678 \\
\hline
\end{tabular}


Table 8 Validity and Reliability Statistics for eWOM model

\begin{tabular}{llllll}
\hline \multicolumn{6}{l}{ Validity and reliability statistics } \\
\hline Construct & Mean & Std. deviation & AVE (Avg. variance Extracted) & CR (Composite Reliability) & Cronbach's Alpha \\
\hline & Statistic & Statistic & Statistic & Statistic & Statistic \\
SC & 3.18 & 1.15 & .623 & .920 & .895 \\
SH & 3.01 & 0.87 & .598 & .807 & .867 \\
MC & 3.04 & 1.19 & .607 & .905 & .874 \\
WC & 3.88 & 0.73 & .617 & .763 & .843 \\
EW & 3.16 & 0.83 & .647 & .815 & .892 \\
\hline
\end{tabular}

credibility is measured from three observed variables named as website popularity, website reliability, and website attractiveness. However, the item of website attractiveness was rejected in CFA analysis due to low item loading. The evidence proves that website credibility stands as a significant factor in predicting eWOM effectiveness. In other words, the perceived popularity and reliability of the platform where eWOM review is presented influence the purchase intention, attitude, and brand image, which is in line with the findings of studies of Cheng \& Zhou 2010 and Ali 2018.

As one of the first to go beyond the traditional notion of source credibility, this study gives a more comprehensive picture of the determinants of eWOM effectiveness and reveals that consumers' assessments of eWOM communications are more complex than previously thought. The author of online reviews is perceived as a significant indicator of eWOM effectiveness on consumer behaviour, but message characteristics and website credibility also influence. The pandemic of COVID-19 has infuses the rapid growth in online consumer behaviour to a greater extent, and therefore, this study will be a significant finding in the literature.

Overall, this research shows that all the factors mentioned above are a strong predictor of eWOM effectiveness for online reviews. Therefore, marketers should encourage the development of eWOM strategies pertaining to these factors. The study recommends the marketers design and manage a consumer review system. This consumer review system will strengthen the visibility of eWOM communication more systematically and help identify more effective eWOM communication that influences consumer behaviour. The availability of the reviewer's information (e.g. profile information, and actual usage experiences) might validate the contributed review. Also, source homophily can be predicted by the use of machine learning, and eWOM displays should be made accordingly. Emphasis on the message characteristics can be used to design the consumer review system. Consistent with prior studies, message sidedness, message volume, message rating, message consistency, and message argument quality have been found to be more effective in perceived message credibility. Thus, it is suggested that marketers integrate such review systems advocating and assisting the reviewer in producing a eWOM message contenting above mentioned message characteristics. Additionally, online retailing sites could provide a review format and guidelines with appropriate product/service dimensions that allow reviewers to express both positive and negative feedback. This will, in return, make the websites for a credible platform of eWOM communication.

\section{Conclusion}

The major contribution of this research is the comprehensive view of eWOM communication in this exponentially growing online consumer era. The study has taken four different dimensions to establish and measure eWOM communication during COVID19 pandemics. The data analysis provides strong evidence that source credibility, source homophile, message characteristics, and website credibility have a positive association with eWOM effectiveness in the Indian context for consumer electronic products 
reviews on online retailing. The credibility of the source and website are two broad sub-construct to predict eWOM communication's impact. In that situation, it is worthwhile to analyse the potential eWOM impact consequences of various source credibility and website credibility configurations. The same could be the case in speculating the relationship between source credibility and message characteristics. This proves that ELM's central and peripheral routes of information processing are significant and consumer takes both the routes for decisions they make.

To extend this research, future studies should strive to expand on this study's conclusions by including more source types, which is not a consideration in the present study. Three key sources dominate today's online consumer review landscape: anonymous and genuine Internet users, professional gatekeeper organisations that create content for "third-party" websites, and marketers who generate reviews for promotional purposes (Dou et al. 2012). This study concentrated on reviews submitted anonymously to avoid the perceived bias associated with commercial or sponsored reviews. Future research should focus on the source's effects on the message's credibility and quality. Source homophily is a significant factor for the receiver to adopt a eWOM message. Therefore, a study on profiling source homophile in different product contexts for different receivers could help extend the current research. Finally, this study did not evaluate the effect of the purchase price, buying motivation, or product selection on customers' perceptions of credibility. Besides, the study has chosen consumer electronic product category in Indian e-tailing sector which can be extended to other contexts in the future research. As online consumers are growing increasingly during this pandemic of COVID-19, the study gives a decisive milestone towards understanding how eWOM functions as a powerful and impactful instrument in this scenario.

\section{Declarations}

Funding Not applicable.

Conflict of interest The authors declare that they have no conflict of interest.

Availability of data and material Data is available.
Code availability (software application or custom code) SPSS 22.0 version (AMOS: 21).

Ethical approval The research follows all ethical standards.

Consent to participate The data is collected with participants consent. A Google form was administrated by keeping the pandemic situation in mind.

Consent for publication This research work is my original work, and currently, it is not under consideration for publication elsewhere. I agree on publication by this journal if my manuscript is found suitable.

\section{References}

Al-Haidari N, Coughlan J (2014) The influence of electronicword-of-mouth on consumer decision-making for beauty products in a Kuwaiti Women's online community. J Contemp East Asia 13(2):3-14

Ali, Y. S. (2018). Electronic word of mouth engagement model in social commerce. In: International conference of reliable information and communication technology, Springer, Cham, (pp 985-994)

Amblee N, Bui T (2011) Harnessing the influence of social proof in online shopping: the effect of electronic word of mouth on sales of digital microproducts. Int J Electron Commer 16(2):91-114

Ardyan E, Kurniawan D, Istiatin I, Luhgiatno L (2021) Does customers' attitude toward negative eWOM affect their panic buying activity in purchasing products? Customers satisfaction during COVID-19 Pandemic in Indonesia. Cogent Business \& Management 8(1): 1952827

Arndt J (1967) Role of product-related conversations in the diffusion of a new product. J Market Res 4(3):291-295

Bartholomew DJ, Steele F, Moustaki I (2008). Analysis of multivariate social science data. statistics in the social and behavioral sciences series (2nd ed.), Abingdon, UK: Taylor \& Francis. ISBN 978-1584889601.

Baur T, Nyström B. (2017) The effect of eWOM components on brand attitude and purchase intention: a cross country study between Germany and Sweden.

Benlian A, Titah R, Hess T (2010) Provider-vs. User-generated Recommendations on E-Commerce websites-comparing cognitive, affective and relational effects

Beyers J, Braun C (2014) Ties that count: explaining interest group access to policymakers. J Public Policy 34(1):93-121

Brown JJ, Reingen PH (1987) Social ties and word-of-mouth referral behavior. J Consumer Res 14(3):350-362

De Bruyn A, Lilien GL (2004) A multi-stage model of word of mouth through electronic referrals. $e B R C$ Research Paper Series, (ref. 2004-02).

Chau M, Cao J, Knotts T, Xu J (2009) Word of mouth marketing through online social networks

Cheng X, Zhou M (2010) Study on effect of eWOM: a literature review and suggestions for future research. In: 2010 International conference on management and service science. IEEE, (pp 1-4) 
Cheung CM, Thadani DR (2012) The impact of electronic wordof-mouth communication: a literature analysis and integrative model. Decis Support Syst 54(1):461-470

Cheung M, Luo C, Sia C, Chen H (2009) Credibility of electronic word-of-mouth: informational and normative determinants of online consumer recommendation. Int $\mathbf{J}$ e-Commerce 13(4):9-38

Chevalier JA, Mayzlin D (2006) The effect of word of mouth on sales: online book reviews. J Mark Res 43(3):345-354

Creswell, J. W. (2013) Steps in conducting a scholarly mixed methods study

Daowd A, Hasan R, Eldabi T, Rafi-ul-Shan PM, Cao D, Kasemsarn N (2021) Factors affecting eWOM credibility, information adoption and purchase intention on generation Y: a case from Thailand. J Enterprise Inform Manage 34(3):838-859

Davis A, Khazanchi D (2008) An empirical study of online word of mouth as a predictor for multi-product category e-commerce sales. Electron Mark 18(2):130-141

Dou L, You J, Yang J, Chen CC, He Y, Murase S, Yang Y (2012) Tandem polymer solar cells featuring a spectrally matched low-bandgap polymer. Nat Photonics 6(3):180-185

Field A (2009) Logistic regression. Discovering Statistics Using SPSS 264:315

Fishbein M, Ajzen I (1977) Belief, attitude, intention, and behavior: an introduction to theory and research. Philos Rhetoric 10(2)

Godes D, Mayzlin D (2004) Using online conversations to study word-of-mouth communication. Mark Sci 23(4):545-559

Gupta P, Harris J (2010) How e-WOM recommendations influence product consideration and quality of choice: A motivation to process information perspective. J Bus Res 63(9-10): 1041-1049

Hair, e. a. (2009). Multivariate data analysis. Chennai, Tamil Naidu, India, south Asian Edition: 7th Edition, Pearson Eduvation Ltd

Hennig-Thurau T, Gwinner KP, Walsh G, Gremler DD (2004) Electronic word-of-mouth via consumer-opinion platforms: what motivates consumers to articulate themselves on the Internet? J Interact Mark 18(1):38-52

Ismagilova E, Dwivedi YK, Slade E (2020) Perceived helpfulness of eWOM: Emotions, fairness and rationality. J Retail Consumer Serv 53:101748

Ismagilova E, Dwivedi YK, Slade E, Williams MD (2017) Impact of eWOM. In: Electronic Word of Mouth (eWOM) in the Marketing Context. SpringerBriefs in Business. Springer, Cham

Jake, L. (2020). Word-of-mouth-marketing-during-covid-19. Retrieved 3 7, 2021, from https://www.referralcandy.com/ blog : https://www.referralcandy.com/blog/word-ofmouth-marketing-during-covid-19/

Kala D, Chaubey DS (2018) Impact of electronic word of mouth on brand image and purchase intention towards lifestyle products in India. Pacific Bus Rev Int 10(9):135-144

Katz E, Lazarsfeld PF (1955) Personal influence: the part played by people in the flow of mass communications. Free Press, New York

Kim J, Gupta P (2012) Emotional expressions in online user reviews: How they influence consumers' product evaluations. J Bus Res 65(7):985-992
Kim S, Kandampully J, Bilgihan A (2018) The influence of eWOM communications: an application of online social network framework. Comput Hum Behav 80:243-254

Kotler P. (2020). The-consumer-in-the-age-of-coronavirus. Retrieved 3 3, 2021, from https://sarasotainstitute.global: https://sarasotainstitute.global/the-consumer-in-the-ageof-coronavirus/

Lee J, Lee JN (2009) Understanding the product information inference process in electronic word-of-mouth: an objectivity-subjectivity dichotomy perspective. Inf Manag 46(5):302-311

Lee D, Kim HS, Kim JK (2012) The role of self-construal in consumers' electronic word of mouth (eWOM) in social networking sites: a social cognitive approach. Comput Hum Behav 28(3):1054-1062

Lerrthaitrakul W, Panjakajornsak V (2014) The impact of electronic word-of-mouth factors on consumers' buying decision-making processes in the low cost carriers: a conceptual framework. Int J Trade Econ Financ 5(2):142

Litvin SW, Goldsmith RE, Pan B (2008) Electronic word-ofmouth in hospitality and tourism management. Tour Manage 29(3):458-468

Luo Y, Xu X (2021) Comparative study of deep learning models for analyzing online restaurant reviews in the era of the COVID-19 pandemic. Int J Hosp Manag 94:102849

Mishra A, Satish SM (2016) eWOM: extant research review and future research avenues. Vikalpa 41(3):222-233

Neumann M (2015) What does the research tell us about wordof-mouth communication?-A literature review. University of Rostock, Germany

Ngarmwongnoi C, Oliveira JS, AbedRabbo M, Mousavi S (2020) The implications of eWOM adoption on the customer journey. J Consumer Market 37(7):749-759. https:// doi.org/10.1108/jcm-10-2019-3450

O'Reilly K, MacMillan A, Mumuni AG, Lancendorfer KM (2016) Extending our understanding of eWOM impact: the role of source credibility and message relevance. J Internet Commerce 15(2):77-96

Park DH, Kim S (2008) The effects of consumer knowledge on message processing of electronic word-of-mouth via online consumer reviews. Electr Commer Res Appl 7(4):399-410

Park C, Lee TM (2009) Information direction, website reputation and eWOM effect: a moderating role of product type. J Bus Res 62(1):61-67

Petty RE, Cacioppo JT (1986) The elaboration likelihood model of persuasion. In: Communication and persuasion. Springer, New York, (pp 1-24)

Podsakoff NP (2003) Common method biases in behavioral research: a critical review of the literature and recommended remedies. J Appl Psychol 885(879):10-1037

Rani A, Shivaprasad HN. (2018) Determinants of electronic word of mouth persuasiveness: a conceptual model and research propositions, J Contemp Manage Res, 12(2)

Rani A, Shivaprasad HN (2018) Electronic word of mouth (eWOM) strategies to manage innovation and digital business model. In: I. Nilanjan ray, Managing Diversity, innovation and infrastructure in business world, NY, USA: IGI Global, (pp 41-63)

Rani A, Itam U, Shivaprasad HN (2021). Determinants of customer engagement in electronic word of mouth (eWOM) 
communication. In Insights, Innovation, and Analytics for Optimal Customer Engagement . IGI Global, (pp 196-225)

Rani A, Shivaprasad HN (2019) Where electronic word of mouth stands in consumer information search: an empirical evidence from India. UNNAYAN: Int Bul Manag Econ 10(1):36-46

Saleem A, Ellahi A (2017) Influence of electronic word of mouth on purchase intention of fashion products in social networking websites. Pakistan J Commerce Social Sci (PJCSS) 11(2):597-622

Saremi HQ (2014) Effectiveness of electronic word of mouth recommendations. McMaster University, Canada

Senecal S, Nantel J (2004) The influence of online product recommendations on consumers' online choices. J Retail 80(2):159-169

Shivaprasad HN, Rani A (2020) Building web-analytics system to measure perceived source credibility in electronic word of mouth communication. Int J Inform Syst Social Change (IJISSC) 11(2):1-13

Steffes EM, Burgee LE (2009) Social ties and online word of mouth. Internet Res 19(1):42-59

Subramani MR, Rajagopalan B (2003) Knowledge-sharing and influence in online social networks via viral marketing. Commun ACM 46(12):300-307

Torlak O, Ozkara BY, Tiltay MA, Cengiz H, Dulger MF (2014) The effect of electronic word of mouth on brand image and purchase intention: an application concerning cell phone brands for youth consumers in Turkey. J Market Develop Compet 8(2):61

Verma S, Yadav N (2021) Past, present, and future of electronic word of mouth (EWOM). J Interact Mark 53:111-128
Vogt BA, Vogt L, Laureys S (2006) Cytology and functionally correlated circuits of human posterior cingulate areas. Neuroimage 29(2):452-466

Wang X (2011) The effect of inconsistent word-of-mouth during the service encounter. J Serv Mark 25(4):252-259

Wern LJ, Sarafudin NKN, Norhisham NS, Zulkifli NEF (2016) The effectiveness of Electronic Word-of-Mouth (eWOM) on consumer purchase intention among Generation-Y (Doctoral dissertation, Faculty of Entrepreneurship and Business).

Wu MH (2013). Relationships among source credibility of electronic word of mouth, perceived risk, and consumer behavior on consumer generated media.

Wu PCS, Wang Y-C (2011) The influences of electronic wordof-mouth message appeal and message source credibility on brand attitude. Asia Pac J Mark Logist 23(4):448-472

Yaylı A, Bayram M (2012) E-WOM: The effects of online consumer reviews on purchasing decisions. Int $\mathrm{J}$ Internet Market Advert 7(1):51-64

Yin D, Bond SD, Zhang H (2014) Anxious or angry? Effects of discrete emotions on the perceived helpfulness of online reviews. MIS Quar 38(2):539-560

Zarrad H, Debabi M (2015) Analysing the effect of electronic word of mouth on tourists' attitude toward destination and travel intention. Int Res J Social Sci 4(4):53-60

Zhang JQ, Craciun G, Shin D (2010) When does electronic word-of-mouth matter? a study of consumer product reviews. J Bus Res 63(12):1336-1341

Publisher's Note Springer Nature remains neutral with regard to jurisdictional claims in published maps and institutional affiliations. 